\title{
Australian Journal of

\section{Behavior of neem seedlings (Azadirachta indica) irrigated with saline water in the soil with biofertilizer and drainage}

\section{Francisco de Oliveira Mesquita ${ }^{1}$, Rafael Oliveira Batista*2, Lourival Ferreira Cavalcante ${ }^{3}$, Fabrícia Gratyelli Bezerra Costa ${ }^{4}$, Antônio Gustavo de Luna Souto ${ }^{3}$, Daniela da Costa Leite Coelho ${ }^{2}$, Ketson Bruno da Silva ${ }^{2}$, Francisco Xavier de Oliveira Filho}

${ }^{1}$ Federal University of Cariri, Department of Agronomy, 63.048-080, Crato city, Ceará State, Brazil

${ }^{2}$ Rural Federal University of Semi-arid, Department of Engineering and Environmental Sciences, 59.625-900, Mossoró city, Rio Grande do Norte State, Brazil

${ }^{3}$ Federal University of Paraíba, Department of Soil and Rural Engineering, 58.397-900, Areia city, Paraíba State, Brazil

${ }^{4}$ Rural Federal University of Semi-arid, Department of Agricultural Science and Forestry Science, 59.625-900, Mossoró city, Rio Grande do Norte State, Brazil

\section{*Corresponding author: rafaelbatista@ufersa.edu.br}

\section{Abstract}

We studied the behavior for neem seedlings subjected to irrigation water salinity and bovine biofertilizer and soil drainage. An experiment was carried during the period of January to June/2016 in greenhouse with plants grown in pots. The experimental design was a randomized block with factorial scheme $5 \times 2 \times 2$ and four repetitions. The factors consisted of application of the five levels of irrigation water salinity: 0.5 (control treatment), 1.5, 3.0, 4.5 and $6.0 \mathrm{dS} \mathrm{m}^{-1}$, in soil without and with bovine biofertilizer (2), tested in the absence and presence (2) of drainage of soil. The variables analyzed were the electrical conductivity of saturated extract, emergency velocity index, plants height, stem diameter, number of leaves, dry weight of shoot, root and total. The 30-dayold plants were irrigated daily with saline waters (treatments) in volumes sufficient to maintain the soil with water content at level of field capacity. Neem seedlings were negatively affected by increased salinity of irrigation water. Since the growth is affected from the electrical conductivity of $0.5 \mathrm{dS} \mathrm{m}^{-1}$; therefore, we conclude that the species is considered to be sensitive to salinity. The results showed that application of bovine biofertilizer and soil drainage are agricultural practices that can minimize the effects of the salts the neem seedlings but does not eliminate it.

Keywords: Azadirachta indica, biofertilization, salinization.

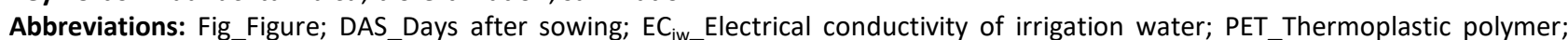
pH_Hydrogenation power; $\mathrm{Ca}^{2+}{ }_{-}$Calcium; $\mathrm{Mg}^{2+}$-Magnesium; $\mathrm{Na}^{+}$Sodium; $\mathrm{K}^{+}$- Potassium; $\mathrm{Cl}-$ _Chlorine; $\mathrm{HCO}_{3}{ }_{-}^{-} \mathrm{Bicarbonate}^{-} \mathrm{SO}_{4}{ }^{2-}=$ Sulfate; DAP_days after planting; $\mathrm{R}^{2}$ _coefficient of determination; TDB_Total dry biomass; LDB_leaves dry biomass; $\mathrm{SDB}_{-}$stem dry biomass, $\mathrm{RDB}$ _roots dry biomass.

Introduction

The growing need to increase food production constitutes a serious scientific and technological challenge which has required expansion of the cultivated areas. However, this search not only takes into account the incorporation of agricultural areas suitable for cultivation of neem, but also harnesses the degraded areas especially in semiarid regions, salt affected soils, and waters with inferior quality, such as those with high salinity (Bernard et al., 2010; Pandey et al., 2017; Liang et al., 2018).

For production of good quality neem seedling in semiarid regions, efficient and low cost methodologies should be adopted. It has been reported that neem is moderately tolerant to salinity during the first year but may have their growth inhibited by salinity and sodicity and other limitations such as water shortage in terms of quantity and quality (Martins et al., 2010; Freire et al., 2010; Pedrotti et al., 2015; Rajput et al., 2018).

According to Yang et al. (2011), Souza et al. (2017) and Neves et al. (2018) it is difficult to grow or increase the productivity of many crops in periods of drought and high temperatures especially under high salt conditions. In this sense, one of the methods to minimize the deleterious effects of salinity is through using soluble salts leaching present in the root zone. On the other hand, the major concern with the water used in agricultural soils is the degradation of soils by the excess of salts present in irrigation water. Therefore, some alternative methods have been employed such as organic farming, among them, the bovine biofertilizer, supplied in liquid form to the soil (Mesquita et al., 2015; Sá et al., 2015; Byrt et al., 2018). 
The first requirement for the recovery of any salt affected soil is to perform adequate drainage. In a well-drained soil, the salinity can be reduced into a tolerable level (Liang et al., 2018). The quantity of water needed to wash the soil profile is determined according to of the initial level of soil salinity, the final desired level of salt, the physical characteristics of the soil, the depth (depends on of the culture to be explored) and other properties of soil to be retrieved. It also depends on the method of soil washing (Rajput et al., 2018). The positive action of bovine biofertilizer for edaphic improvement in terms of aeration dynamics and water in the soil mainly depend on the humic substances originated from the organic matter, which can mitigate the depressive effects of salinity saline waters to the plants (Baalousha et al., 2006; Souza et al., 2016; Neves et al., 2018). The use of organic inputs should inhibit the saline action of the waters and stimulate the initial growth of neem plants during seedling formation (Mellek et al., 2010; Liu et al., 2018; Neves et al., 2018).

However, little information is available on the behavior of the neem irrigated with saline water and the application of techniques that minimize the effects of the salts on plants, along with the drainage system and the addition of bovine biofertilizer in the soil. In that sense, the experiment was conducted under protected environment to evaluate the performance of neem seedlings subjected to different salinity levels of irrigation water in the soil with bovine biofertilizer and soil drainage.

\section{Results and discussion}

\section{Soil salinity}

We measured the electrical conductivity values of the soil before starting the experiment (Table 1) and also 180 days after sowing (Fig. 1). Before experiment, the soil had the electrical conductivity of $0.79 \mathrm{dS} \mathrm{m}^{-1}$. It was increased up to $17.61 \mathrm{dS} \mathrm{m}^{-1}$ at the end of the experiment in the treatments without soil drainage and with bovine biofertilizer (Fig. 1A). The substrates evaluated by soil drainage and increasing salinity of irrigation water, the values varied from 11.41 to $13.50 \mathrm{dS} \mathrm{m}^{-1}$ in soil with and without bovine biofertilizer, respectively (Fig. 1B).

A high electrical conductivity value of $3.39 \mathrm{dS} \mathrm{m}^{-1}$ was observed in the soil treated with biofertilizer compared to the no biofertilizer treatment. This value might be corresponded to a severe water restriction due to soil salinization (Ayers and Westcot, 1999). In addition, the average temperature in the greenhouse (place of experiment) reached up to 44.9 으. This high temperature may also have contributed to the significant increase in salinity with negative its effects on the vegetative behavior of plant (Cavalcante and Cavalcante, 2006; Liang et al., 2018).

Significant effect on the interaction of salinity $\times$ biofertilizer on the index of germination velocity of neem seedlings was also observed. The viability of neem seeds was $89 \%$, before the application of treatments. It is verified that treatment with bovine biofertilizer stimulated the speed of seedling emergence of neem at 50 days after sowing (DAS) (Fig. 2). Application of biofertilizer linearly increased velocity index of emergency from 0.238 to 0.99 due to using smaller and

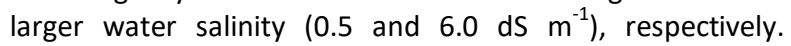

However, under organic compost, this parameter was reduced by $35.67 \%$ with increase of salinity from 0.5 to 6.0 $\mathrm{dS} \mathrm{m}^{-1}$. In this sense, there was greater energy expenditure by neem plants compared to the normal conditions.

The tendency and effects of bovine biofertilizer in reducing harmful action of salts on neem seedling emergence was seriously compromised by the salts. This was similar to those presented by Freire et al. (2010) and Neves et al. (2018), who evaluated the emergence and initial growth of castor beans (Ricinus communis) and guava irrigated with saline water. A similar tendency was also recorded by Nunes et al. (2009), which showed a high increase in salinity levels of irrigation water in soil with bovine biofertilizer, resulted in the decrease of the emergency speed index in noni seedlings (Morinda citrifolia).

Generally, the use of biofertilizer in arid and semiarid regions should be aimed to potentiate the growth and the yield of the crops, because its positive biological effects will happen in later years after application. The biological fertilizers have greater acceptance due to lower costs, if compared with the chemicals products. They also leave no or less residual effects on the environment (Boraste et al., 2009; Mellek et al., 2010; Silva et al., 2011).

\section{Morphogenic characteristics of plants}

In soil without the agricultural drainage (Fig. 3A), the growth (height) of plants were ranged from 13.98 until $49.54 \mathrm{~cm}$, in the soil without and with bovine biofertilizer, respectively. However, plants showed inhibition in growth or loss of physiological quality and biological processes after applying saline water $\left(0.5 \mathrm{dS} \mathrm{m}^{-1}\right)$. Fig. $3 \mathrm{~B}$, shows that in spite of the high dispersion of data, the height of neem seedlings were increased from 16.61 to $38.28 \mathrm{~cm}$, in soil without and with the organic input, respectively, at the highest level of salinity tested in the experiment $\left(6.0 \mathrm{dS} \mathrm{m}^{-1}\right)$. This response can be probably attributed to the osmotic component resulting from high concentrations of dissolved salts in the soil solutions. This will reduce the osmotic potential of the solution, consequently decreasing the availability of water for plants (García et al., 2011).

The number of leaves in neem seedlings responded to the effects of salinity and biofertilizers (Fig. 4). The plants of neem evaluated at the end of experiment, showed a drastic reduce in leaves from 18 to 9 and 37 to 26 , when subjected to the soil without and with bovine biofertilizer, where these dates refers to lower and higher salinity of irrigation water of 0.5 and $6.0 \mathrm{dS} \mathrm{m}^{-1}$, respectively (Fig. 4).

The increase of salt stress in irrigation water inhibited the emergence of new leaves, reflecting negatively on the expansion of leaf area, and thereby damaging the physiological and biochemical processes of the neem plant. Reduction in leaves number were also reported by Rebequi et al. (2009) and Mesquita et al. (2012) during the formation of seedlings of yellow passion fruit (Passiflora edulis Sims) and rangpur lemon (Citrus limonia Osbeck) using irrigation with saline water, with smaller declines in plant treatments with bovine biofertilizer. Under these conditions, the reduction in the number of leaves is caused by abscission, in function of senescence precocious by the toxic effects of salts excess in the irrigation water (Liang et al., 2018). 
Table 1. Physical and chemical attributes in relation to fertility and soil salinity in the first $0.2 \mathrm{~m}$ depth.

\begin{tabular}{|c|c|c|c|c|c|}
\hline Physical & Value & Fertility & Value & Salinity & Value \\
\hline $\mathrm{SD}\left(\mathrm{g} \mathrm{cm}^{-3}\right)$ & 1.24 & $\mathrm{pH}$ in water(1: 2.5$)$ & 5.08 & ECse $\left(\mathrm{dS} \mathrm{m}^{-1}\right)$ & 0.79 \\
\hline $\mathrm{PD}\left(\mathrm{g} \mathrm{cm}^{-3}\right)$ & 2.78 & $\operatorname{SOM}\left(\mathrm{g} \mathrm{Kg}^{-1}\right)$ & 18.31 & $\mathrm{pH}$ & 6.71 \\
\hline $\operatorname{TP}\left(\mathrm{m}^{3} \mathrm{~m}^{-3}\right)$ & 0.54 & $P\left(\mathrm{mg} \mathrm{dm}^{-3}\right)$ & 1.82 & $\mathrm{Ca}^{2+}\left(\mathrm{mmol}_{\mathrm{c}} \mathrm{L}^{-1}\right)$ & 1.72 \\
\hline Sand $\left(\mathrm{g} \mathrm{kg}^{-1}\right)$ & 557 & $\mathrm{~K}^{+}\left(\mathrm{mg} \mathrm{dm}^{-3}\right)$ & 45,01 & $\mathrm{Mg}^{2+}\left(\mathrm{mmol}_{\mathrm{c}} \mathrm{L}^{-1}\right)$ & 0.67 \\
\hline Silte $\left(\mathrm{g} \mathrm{kg}^{-1}\right)$ & 63 & $\mathrm{Ca}^{2+}\left(\mathrm{cmol}_{\mathrm{c}} \mathrm{dm}^{-3}\right)$ & 0.38 & $\mathrm{Na}^{+}\left(\mathrm{mmol}_{\mathrm{c}} \mathrm{L}^{-1}\right)$ & 0.25 \\
\hline Clay $\left(\mathrm{g} \mathrm{kg}^{-1}\right)$ & 380 & $\mathrm{Mg}^{2+}\left(\mathrm{cmol}_{\mathrm{c}} \mathrm{dm}^{-3}\right)$ & 0.27 & $\mathrm{~K}^{+}\left(\mathrm{mmol}_{\mathrm{c}} \mathrm{L}^{-1}\right)$ & 110 \\
\hline $\operatorname{CDW}\left(\mathrm{g} \mathrm{kg}^{-1}\right)$ & 26 & $\mathrm{Na}^{+}\left(\mathrm{cmol}_{\mathrm{c}} \mathrm{dm}^{-3}\right)$ & 0.11 & $\mathrm{Cl}^{-}\left(\mathrm{mmol}_{\mathrm{c}} \mathrm{L}^{-1}\right)$ & 4.17 \\
\hline DG (\%) & 93.26 & $\mathrm{H}^{+}+\mathrm{Al}^{3+}\left(\mathrm{cmol}_{\mathrm{c}} \mathrm{dm}^{-3}\right)$ & 5.64 & $\mathrm{CO}_{3}^{2-}\left(\mathrm{mmol}_{\mathrm{c}} \mathrm{L}^{-1}\right)$ & - \\
\hline ID (\%) & 6.84 & $\mathrm{Al}^{3+}\left(\mathrm{cmol}_{\mathrm{c}} \mathrm{dm}^{-3}\right)$ & 0.87 & $\mathrm{HCO}_{3}^{-}\left(\mathrm{mmol}_{\mathrm{c}} \mathrm{L}^{-1}\right)$ & 1.51 \\
\hline $\mathrm{H}_{\mathrm{fc}}\left(\mathrm{g} \mathrm{kg}^{-1}\right)$ & 16.84 & $\mathrm{SB}\left(\mathrm{cmol}_{\mathrm{c}} \mathrm{dm}^{-3}\right)^{\prime}$ & 0.88 & $\mathrm{SO}_{4}{ }^{2-}\left(\mathrm{mmol}_{\mathrm{c}} \mathrm{L}^{-1}\right)$ & 2.21 \\
\hline $\mathrm{H}_{\text {pwp }}\left(\mathrm{g} \mathrm{kg}^{-1}\right)$ & 4.54 & $\operatorname{CEC}\left(\mathrm{cmol}_{\mathrm{c}} \mathrm{dm}^{-3}\right)$ & 6.52 & $\operatorname{SAR}\left(\mathrm{mmolL}^{-1}\right)^{1 / 2}$ & 0.22 \\
\hline WA $\left(\mathrm{g} \mathrm{kg}^{-1}\right)$ & 4.54 & $\mathrm{~V}(\%)$ & 13.49 & $\operatorname{ESP}(\%)$ & 3.83 \\
\hline
\end{tabular}

$\mathrm{SD}=$ density of soil; $\mathrm{PD}=$ particle density; $\mathrm{TP}=$ total porosity; $\mathrm{CDW}=$ clay dispersed in water; $\mathrm{DG}=$ Degree of flocculation; $\mathrm{ID}=$ Index of dispersion; $\mathrm{H}_{\mathrm{fc}}=$ Humidity in field capacity; $\mathrm{H}_{\mathrm{pwp}}=\mathrm{Humidity}$ permanent wilting point; $\mathrm{WA}=$ Water available; $\mathrm{SOM}=$ soil organic matter, $\mathrm{P}=$ phosphorus $-\mathrm{Mehlich}-1 ; \mathrm{K}^{+}=$Potassium $-\mathrm{Mehlich}-1 ; \mathrm{Na}^{+}=\operatorname{sodium}-\mathrm{KCl} 1 \mathrm{~mol} / \mathrm{L} ; \mathrm{Ca}^{2+}=\mathrm{calcium}-\mathrm{KCl} 1 \mathrm{~mol} / \mathrm{L} ; \mathrm{Mg}{ }^{2+}=$ magnesium $-\mathrm{KCl} 1 \mathrm{~mol} / \mathrm{L} ; \mathrm{H}^{+}+\mathrm{Al}^{3+}=$ potential acidity - calcium acetate $0.5 \mathrm{~mol} / \mathrm{L}-\mathrm{pH} 7.0 ; \mathrm{Al}^{3+}=$ exchangeable aluminum - calcium acetate $0.5 \mathrm{~mol} / \mathrm{L}-\mathrm{pH} 7.0 ; \mathrm{SB}=\mathrm{Sum}$ of bases $\left(\mathrm{Na}{ }^{+}+\mathrm{K}^{+}+\mathrm{Ca}^{2+}\right.$ $\left.+\mathrm{Mg}^{2+}\right) ; \mathrm{CEC}=$ cation exchange capacity $=\mathrm{SB}+\left(\mathrm{H}^{+}+\mathrm{Al}^{3+}\right)$; $\mathrm{V}=$ value of saturation of bases $(100 \times \mathrm{SB} / \mathrm{CEC})$; ECse = electrical conductivity of the saturation extract; $\mathrm{SAR}=$ sodium adsorption ratio = $\mathrm{Na}^{+} /\left[\left(\mathrm{Ca}^{2+}+\mathrm{Mg}^{2+}\right) / 2\right]^{1 / 2} ; \mathrm{ESP}=$ exchangeable sodium percentage $\left(100 \times \mathrm{Na}^{+} / \mathrm{CEC}\right)$.
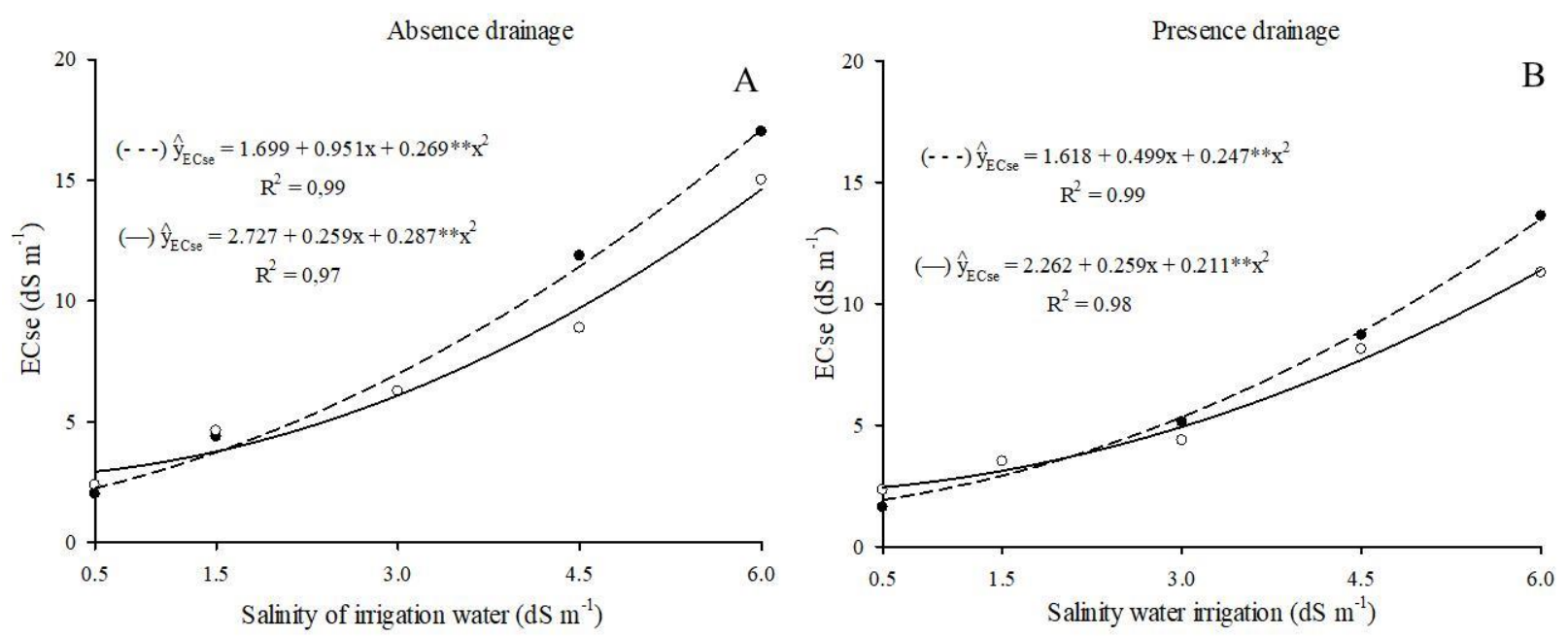

Fig 1. Electrical conductivity of saturation extract of soil without (- - ) and with (-) bovine biofertilizer, in absence and presence of the soil drainage in period to 180 days after sowing (DAS). Areia, Paraíba state, Brazil, 2011.

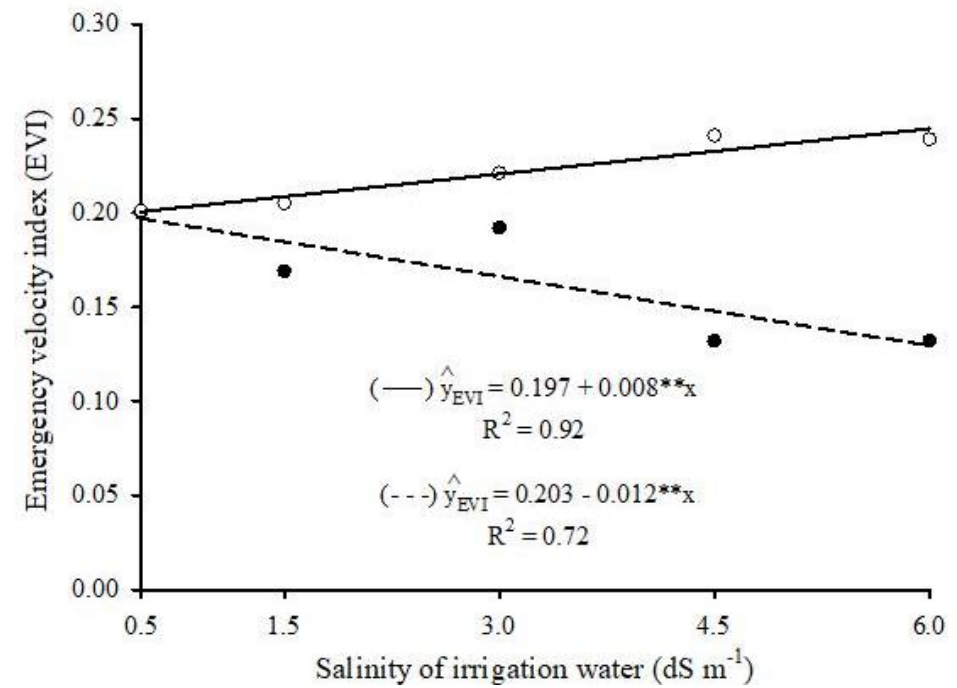

Fig 2. Emergence speed Index of the neem seedling in soil without (- - ) and with (-) bovine biofertilizer according the salinity of irrigation water in the period of 50 DAS. Areia, Paraíba state, Brazil, 2011. 

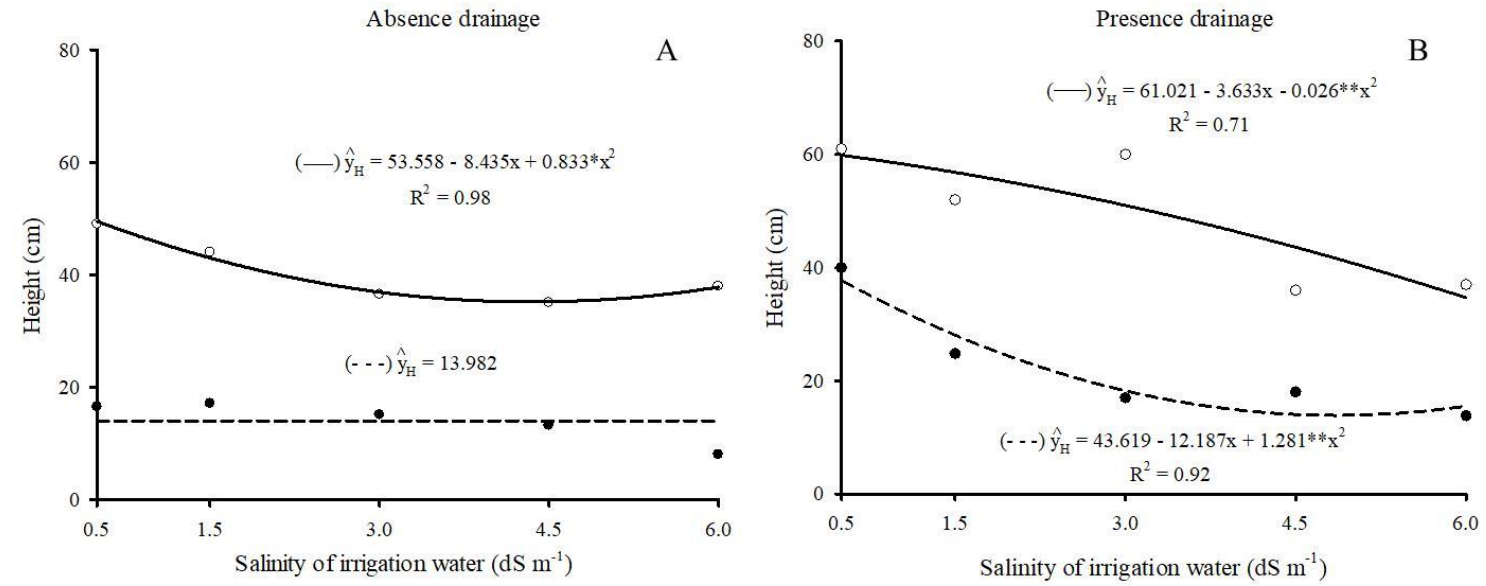

Fig 3. Plants height of neem in soil without (- - ) and with (-) bovine biofertilizer, in soil without $\left(D_{1}\right)$ and with $\left(D_{2}\right)$ drainage of treatments in rate the irrigation water salinity developed in period to 180 days after sowing (DAS), Areia, Paraíba state, Brazil, 2011.

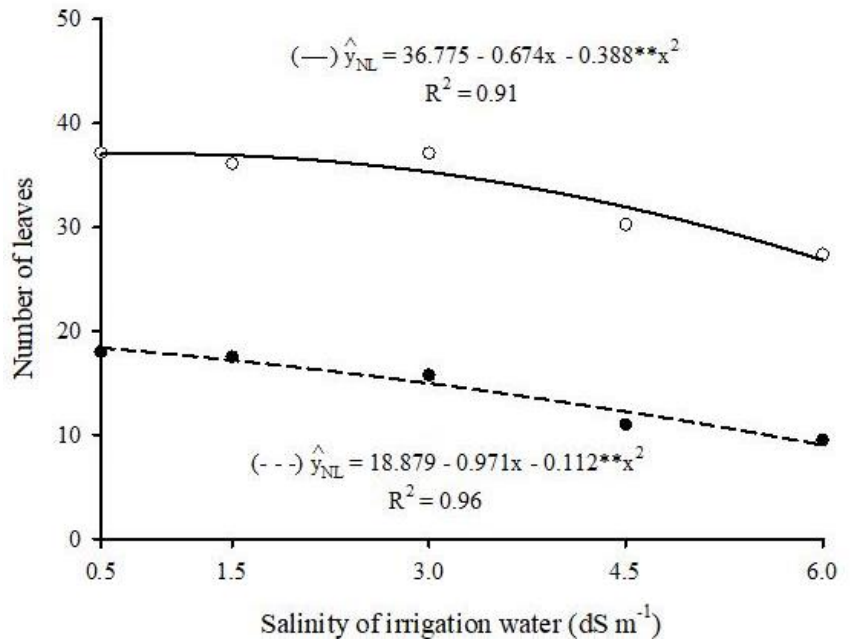

Fig 4. Number of leaves of the neem plants in soil without (- - -) and with (-) bovine biofertilizer using irrigation water salinity developed in period to 180 days after sowing (DAS). Areia, Paraíba state, Brazil, 2011.

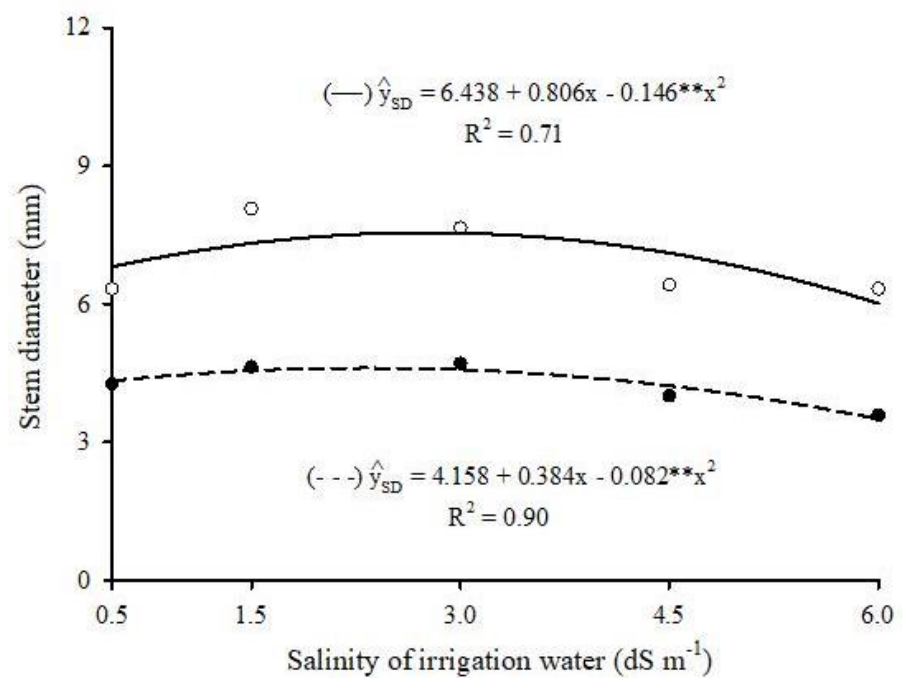

Fig 5. Stem diameter of the neem plants in soil without (- - -) and with (-) bovine biofertilizer treatments using different saline water treatments, 180 days after sowing (DAS), Areia, Paraíba state, Brazil, 2011. 


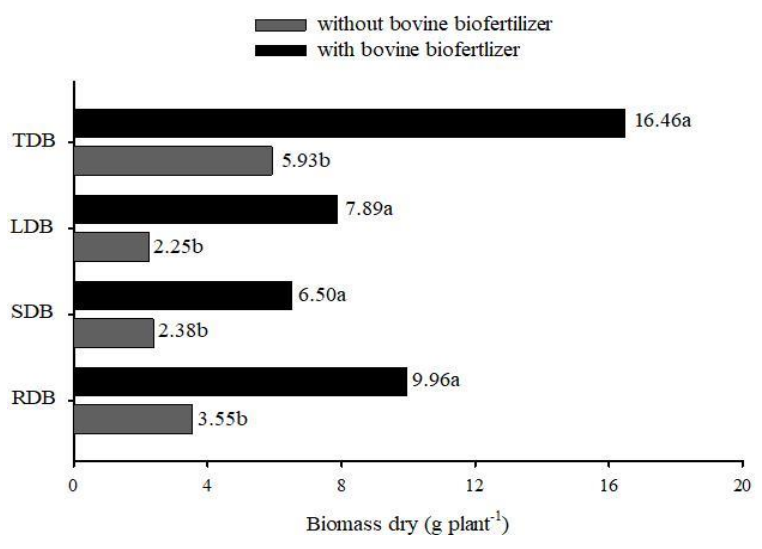

Fig 6. Values of total dry biomass (TDB), leaves dry biomass (LDB), stem dry biomass (SDB) and roots dry biomass (RDB) of the neem plants in soil without and with bovine biofertilizer, 180 days after sowing (DAS), Areia, Paraíba state, Brazil, 2011.

The stem diameter of the neem plants was influenced significantly by the effects of interaction between biofertilizer and salinity of soil, tested at level of $5 \%$ probability by test $\mathrm{F}$ (Fig. 5). The stem diameter of the neem plants is associated varied from 4.32 to $3.51 \mathrm{~mm}$ in the soil without biofertilizer, under water salinity of 0.50 and $6.0 \mathrm{dS}$ $\mathrm{m}^{-1}$, respectively (Fig. 5). In the soils with bovine biofertilizer, the diameter of the neem plants ranged from 6.80 a 6.01 $\mathrm{mm}$, corresponding to lower and higher water salinity. In soil without biofertilizer, the greatest value of stem diameter of $4.59 \mathrm{~mm}$ was achieved in salinity of $2.76 \mathrm{dS} \mathrm{m}^{-1}$, while in the soil with biofertilizer the greater value of $7.51 \mathrm{~mm}$ was obtained in water salinity of $2.34 \mathrm{dS} \mathrm{m}^{-1}$.

In this sense, it indicates that at end of the experiment, the neem plant had better yield up to $63.61 \%$ higher, under threshold salinity of $2.34 \mathrm{dS} \mathrm{m}^{-1}$. These results are also reported by Asik et al. (2009) to detect harmful effects of humus and humic acid on growth and yield of wheat (Triticum durum) under different levels of sodium chloride. In Fig. 6, we verified that the neem plants grown in soil with bovine biofertilizer produced more biomass with supremacy for roots compared to aerial parts (stem and leaves). This superiority indicates positive action of biofertilizer in mitigating degenerative effects of salinity on the plants. The root dry biomass was ranged from 3.55 to $9.96 \mathrm{~g} \mathrm{plant}^{-1}$. The stem dry biomass oscillated from 2.38 to $6.50 \mathrm{~g} \mathrm{plant}^{-1}$. Regarding the biomass of dry of aerial part (leaves dry biomass); the neem plant showed significant variation in yield (2.25 to 7.89) at the end of the experiment (180 days). Finally, the total dry biomass showed higher values compared to all other factors, having oscillation from 5.93 to $16.46 \mathrm{~g} \mathrm{plant}^{-1}$. The comparative analysis at the end of experiment showed that organic input promoted an increase of $177.58 \%$ in production of the total biomass of neem plant, compared with the soil without biofertilizer. A similar situation was also recorded by Nunes et al. (2018), after evaluating the effects of salt water in the soil with bovine biofertilizer, during the growth initial of neem seedlings.

\section{Materials and methods}

\section{Biological materials}

The seeds of neem (Azadirachta indica) were obtained from fruiting plants with three years of age, belonging to the experimental station of the State Research Company of Paraiba (EMEPA), João Pessoa city, Paraíba State, Brazil. The seeds presented $89 \%$ viability and such experimental unit was represented by a neem plant with two pairs of definitive leaves, fully expanded and without any defect or damage caused by disease, pests and none stress type.

\section{Characterization of experimental location}

The experiment was conducted in protected environment in the period January to June 2016, the Department of Soils and Rural Engineering, Center of Agricultural Sciences, Federal University of Paraiba, located in Areia, Paraiba State, Brazil, located by the points of geographical coordinates $6^{\circ}$ $51^{\prime} 47^{\prime \prime}, 7^{\circ} 02^{\prime} 04^{\prime \prime}$ south latitude and 350 34' $13^{\prime \prime}$ and 350 48' 28 " longitude west of Greenwich, with an altitude of $575 \mathrm{~m}$ above the sea level.

The climate according to the Köppen classification is of type As' (hot and humid), according to Alvares et al. (2013), with average annual precipitation of $1200 \mathrm{~mm}$, the region's average temperature of $24.5^{\circ} \mathrm{C}$, and average relative humidity of $71.5 \%$.

The soil of the experimental area was characterized as Oxisols Yellow-Red distrophic, sandy texture and non-saline (Embrapa, 2013), collected from the first $0.2 \mathrm{~m}$ depth. After collecting material samples they were transported to the laboratory and they were passed through a $2 \mathrm{~mm}$ mesh sieve and the physical attributes and chemical attributes of fertility and salinity were determined according to the methodologies contained in Embrapa (2017) and Richards (1954), as shown in Table 1.

\section{Experiment set up and conduction}

The treatments were distributed in randomized blocks with four replications in a factorial $5 \times 2 \times 2$, referring to five salinity levels of irrigation water: $0.5,1.5,3.0,4.5$ and $6.0 \mathrm{dS}$ $\mathrm{m}^{-1}$ soil; with and without bovine biofertilizer in the liquid form, with and without soil drainage to salts leaching levels. The value of the electrical conductivity of each type of water used for irrigation was obtained by dilution of a strongly saline water barrage $\left(11.4 \mathrm{dS} \mathrm{m}^{-1}\right)$ originating from the Jacaré pond located in the municipality of Remígio, Paraíba State, Brazil. The non-saline water had electrical conductivity of $\left(0.5 \mathrm{~d} \mathrm{Sm}^{-1}\right)$ according to Souto et al. (2013). 
Irrigation was done daily with a volume of water to keep the soil with damp near field capacity, registering each volume applied. The irrigation with no saline water considered as control $\left(E C_{i w}=0.5 \mathrm{dS} \mathrm{m}^{-1}\right)$ and saline waters $\left(E_{\mathrm{iw}}=1.5,3.0\right.$, 4.5, $6.0 \mathrm{dS} \mathrm{m}^{-1}$ ). Each 15 days soil was watered with each type of water to irrigate the plants.

We used plastic pots with a diameter of $0.2611 \mathrm{~m}$ base and $0.35 \mathrm{~m}$ in height, with a maximum capacity of $20 \mathrm{dm}^{3}$. However, each treatment consisted of a drainage system prepared with a $0.02 \mathrm{~m}$ layer of thick gravel $\left(\mathrm{n}^{\circ} .20\right)$ and a layer of the same thickness washed with fine sand. At the bottom of the pots PVC hoses 5/16" $\times 0.8 \mathrm{~mm}$ were connected for drainage of the water. Two liters Percolated PET bottles were used for measurement of $\mathrm{pH}$ and electrical conductivity of the leachate. Each experimental unit consisted of only one neem plant aged 30 days per plastic pot, for standardization of seedling growth.

The drainage system was initiated 63 days after seedling emergence and made every fortnight. The plants were irrigated daily with each water type. On the seventh day of water supply draining of soil was started. At this point, a further volume of each type of water corresponding to $10 \%$ of the volume applied was added to the soil washing and leaching the salts. After stop of drainage, leaching volume was measured and in each treatment the characteristics such as volume of water added, percolated, the volume of water retained in the soil, $\mathrm{pH}$ and electric conductivity of the percolated material were quantified. Then the total volume applied on the seventh day with the volumes supplied daily was calculated. The water drainage is characterized as potentially polluting in terms of the concentration of soluble salts, making it unsuitable for reuse in agriculture according to Diniz et al. (2013).

\section{Physical-chemical analysis of bovine biofertilizer}

The biofertilizer was obtained from the mixture of equal parts of fresh bovine manure and water (no saline and nonchlorinated) in biodigester following anaerobic fermentation for 30 days (Viana et al., 2014). Two days before seeding, the biofertilizer was diluted in ratio 1:1, in non-saline water and then $1.5 \mathrm{dm}^{3}$ was applied, corresponding to $10 \%$ of volume of the substrate $\left(15 \mathrm{dm}^{3}\right)$. For keeping the system up, a hose with $4 \mathrm{~mm}$ of diameter in upper base of the biodigester was installed and the other end immersed in bottle type PET 2L, containing water which was hermetically closed at the end. The liquid biofertilizer was characterized showing the following values: $\mathrm{Ca}^{2+}=1.17, \mathrm{Mg}^{2+}=0.69, \mathrm{Na}^{+}=2.43, \mathrm{~K}^{+}=$ $0.17, \mathrm{Cl}^{-}=3.43, \mathrm{HCO}_{3}^{-}=0.29, \mathrm{CO}_{3}{ }^{2-}=$ (absence), $\mathrm{SO}_{4}{ }^{2-}=0.75$ $\mathrm{mmol}_{\mathrm{c}} \mathrm{L}^{-1}$, and the electrical conductivity at $25^{\circ} \mathrm{C}=3.39 \mathrm{dS}$ $\mathrm{m}^{-1}$ and $\mathrm{pH}=6.74$ according to the methodology presented Richards (1954).

\section{Evaluated characteristics}

At the end of experiment, which was 180 days after planting (DAP), all plants were sacrificed for quantification of dry matter production. The neem seedlings were cut parallel to soil, and soon after, all the roots, stems and shoots were carefully removed. They were then washed with distilled water to remove the excess soil and blotted to remove excess water. The separate parts (roots, stems and leaves) were conditioned in a safe place in the laboratory of plants nutrition. Then the fresh biomass of each of the three bodies was measured with precision balance digital. Subsequently, the vegetative material dried (leaves + root) by drying in kiln with forced air circulation at a temperature of $65^{\circ} \mathrm{C}$ up until reaching a constant biomass. The dry matter was measured using digital electronic balance with accuracy of $0.01 \mathrm{~g}$.

At 30 days after emergence, thinning was carried out by leaving just one vigorous seedling seedling per pot. After sowing the pots were monitored to record the first count of normal seedlings emergence and daily counts until the end of emergence for evaluation of the index of emergency velocity. After this, plants height was measured with millimeter ruler. The stem diameter was determined using a caliper and number leaves.

\section{Statistical analysis}

Data were submitted to analysis of variance using the $F$ test at $5 \%$ probability. Means referring to biofertilizer and drainage were compared by test ' $F$ ' that is conclusive to two factors and means relatives to salinity levels of the water by regression analysis using the statistic program Sisvar 5.1 Build 72 (Ferreira, 2011).

\section{Conclusion}

The bovine biofertilizer and soil drainage improved the growth and development of the neem plants, compared to the soil with and without the respective input regardless of salinity level of irrigation water. The increase of water salinity raised the saline character of the soil and inhibited the growth of the plants, but with less intensity in the treatments with bovine biofertilizer and soil drainage.

\section{Acknowledgment}

At Conselho Nacional de Desenvolvimento Científico e Tecnológico ( $\mathrm{CNPq}$ ) for funding the research grant and the researchers from Instituto Nacional de Ciência e Tecnologia em Salinidade (INCTSal).

\section{References}

Alvares CA, Stape JL, Sentelhas PC, Gonçalves JLM, Sparovek G (2013) Köppen's climate classification map for Brazil. Meteorol Z. 22: 711-728.

Asik BB, Turan MM, Celik H, Katkat V (2009) Effects of humic substances on plant growth and mineral nutrients uptake of wheat (Triticum durum cv. Salihli) under conditions of salinity. Asian J Crop Sci. 1: 87-95.

Ayers RS, Westcot DW (1999) A qualidade da água na agricultura. Campina Grande: UFPB. 153p.

Bernard JH, Rensburg LDV, Bennie ATP (2010) Leaching irrigated saline sandy to sandy loam apedal soils with water of a constant salinity. Irrig Sci. 28: 191-201.

Boraste AK, Vamsi KK, Jhadav A, Khairnar Y, Gupta N, Trivedi S, Patil PC, Gupta G, Mujapara AK, Joshi B (2009) Biofertilizers: A novel tool for agriculture. Int J Microbiol Res. 1: 23-31.

Byrt CS, Munns R, Burton RA, Gilliham M, Wege S (2018) Root cell wall solutions for crop plants in saline soils. Plant Sci. 269: 47-55. 
Cavalcante LF, Cavalcante IHL (2006) Uso de água salina na agricultura. In: Cavalcante L F, Lima EM (eds). Algumas Frutíferas Tropicais e a Salinidade, Jaboticabal: FUNEP. 117.

Diniz BLMT, Cavalcante LF, Mesquita FO, Lima Neto AJ, Nunes JC, Diniz Neto MA (2013) Crescimento inicial e consumo hídrico de nim submetido ao estresse salino e biofertilizante bovino. Rev Bras Ciênc Agrár. 8: 470-475.

Embrapa - Empresa Brasileira de Pesquisa Agropecuária. (2017) Manual de métodos de análise do solo. $3^{\text {rd }}$. Rio de Janeiro: Embrapa, 573p.

Embrapa - Empresa Brasileira de Pesquisa Agropecuária. (2013) Sistema Brasileiro de Classificação de Solos. $3^{\text {rd }}$. Rio de Janeiro: Embrapa, 353p.

Ferreira DF (2011) Sisvar: a computer statistical analysis system. Ciênc Agrotec. 35: 1039-1042.

Freire ALO, Sousa Filho GM, Miranda JRP, Souto PC, Araújo LVC (2010) Crescimento e nutrição mineral do nim (Azadirachta indica A. Juss.) e cinamomo (Melia azedarach Linn.) submetidos à salinidade. Ciênc Florest. 20: 207-215.

García BL, Alcántara LP, Fernández JLM (2011) Soil tillage effects on monovalent cations $\left(\mathrm{Na}^{+}\right.$and $\left.\mathrm{K}^{+}\right)$in vertisols soil solution. Catena. 84: 61-69.

Liang W, Ma X, Wan P, Liu L (2018) Plant salt-tolerance mechanism: A review. Biochem Biophys Res Commun. 495: 286-291.

Liu D, Xie B, Dong C, Liu G, Hud, Qin Y, Li H, Liu H (2018) Effect of fertilizer prepared from human feces and straw on germination, growth and development of wheat. Acta Astronaut. 145: 76-82.

Souto AGL, Cavalcante LF, Nascimento JAM, Mesquita FO, Lima Neto AJ (2013) Comportamento do noni à salinidade da água de irrigação em solo com biofertilizante bovino. Irriga. 18: 42453.

Martins MO, Nogueira RJMC, Azevedo Neto AD, Santos MG (2010) Crescimento de plantas jovens de nim-indiano (Azadirachta indica A. Juss. - Meliaceae) sob diferentes regimes hídricos. Rev Árvore. 34: 771-779.

Mellek JE, Dieckow J, Silva VL, Favaretto N, Pauletti V, Vezzani FM, Souza JLM (2010) Dairy liquid manure and notillage: Physical and hydraulic propertie and carbon stocks in a Cambisol of Southern Brazil. Soil Tillage Res. 110: 6976.

Mesquita EF, Sá FVS, Bertino AMP, Cavalcante LF, Paiva EP, Ferreira NM (2015) Effect of soil conditioners on the chemical attributes of a saline-sodic soil and on the initial growth of the castor bean plant. Semina: Ciênc Agrár. 36: 2527-2538.

Mesquita FO, Cavalcante LF, Pereira WE, Rebequi AM, Lima Neto AJ, Nunes JC (2012) Produção de mudas de maracujazeiro amareloem substrato com biofertilizante bovino irrigado com águas salina. Cienc Suelo. 30: 31-41.
Nunes JAS, Nunes JC, Silva JA, Oliveira AP, Cavalcante LF, Oresca D, Silva OPR (2018) Influence of spacing and application of biofertilizer on growth and yield of okra (Abelmoschus esculentus (L.) Moench). Afr J Biotechnol. 17: 17-23.

Nunes JC, Cavalcante LF, Rebequi AM, Lima Neto AJ, Diniz AA, Silva JJM, Brehm MAS (2009) Formação de mudas de noni sob irrigação com águas salinas biofertilizante bovino no solo. Engenharia Ambiental. 6: 451-463.

Pandey VP, Rani J, Jaiswal N, Singh S, Awasthi M, Shasany AK, Tiwari S, Dwivedi UM (2017) Chitosan immobilized novel peroxidase from Azadirachta indica: Characterization and application. Int J Biol Macromol. 104: 1713-1720.

Pedrotti A, Chagas RM, Ramos VC, Prata APN, Lucas AAA, Santos PB (2015) Causas e consequências do processo de salinização dos solos. REGET. 19: 1308-1324.

Rajput VD, Minkina TM, Behal A, Sushkova SN, Mandzhieva S, Singh R, Gorovtsov A, Tsitsuashvili VS, Purvis WO, Ghazaryan KA, Movsesyan HS (2018) Effects of zinc-oxide nanoparticles on soil, plants, animals and soil organisms: A review. Environ Nanotechnol Monit Manage. 9: 76-84.

Rebequi AM, Cavalcante LF, Nunes JC, Diniz AA, Brehm MAS, Beckmann-Cavalcante MZ (2009) Produção de mudas de limão cravo em substrato com biofertilizante bovino irrigado com águas salinas. Rev de Ciências Agrárias. 32: 219-228.

Richards LA (1954) Diagnostico y rehabilitación de suelos salinos y sódicos. México: Departamento de Agricultura de los Estados Unidos de América, (Manual de Agricultura, 60). 174p.

Sá FVS, Mesquita EF, Costa JD, Bertino AMP, Araújo JL (2015) Influência do gesso e biofertilizante nos atributos químicos de um solo salino-sódico e no crescimento inicial do girassol. Irriga. 20: 46-59.

Silva RCB, Scaramuzza WLMP, Scaramuzza JF(2011) Sintomas de deficiencias nutricionais e matéria seca em plantas de nim, cultivadas em solução nutritiva. Cerne. 17: 17-22.

Souza JTA, Cavalcante LF, Nunes JC, Bezerra FTC, Nunes JAS, Silva AR, Oresca D, Cavalcante AG (2016) Effect of saline water, bovine biofertilizer and potassium on yellow passion fruit growth after planting and on soil salinity. Afr J Agric Res.11: 2994-3003.

Souza RS, Weber OLS, Scaramuzza JF, Ribeiro ES (2017) Concentração de macronutrientes e de sódio em mudas de mogno submetidas ao estresse salino. Nativa. 5: 127-132.

Viana TVA, Lima JGA, Sousa GG, Pinheiro Neto LG, Azevedo BM (2014) Growth, gas exchange and yield of corn when fertigated with bovine biofertilizer. Rev Caatinga. 27: 106114.

Yang J, Zhang L, Hira D, Fukuzaki Y, Furukawa K (2011) Anammox treatment of high-salinity wastewater at ambient temperatura. Bioresour Technol. 102: 2367-2372. 